\title{
CADASTRE AND PROPERTY REGISTER IN REPUBLIC OF BULGARIA
}

\author{
DOI: http://dx.doi.org/10.18509/GBP.2018.49
}

UDC: 528.44:349.418(497.2)

\section{Ganeta Minkova}

Sofia University "Kliment Ohridski", Faculty of Geology and Geography, Republic of Bulgaria

\begin{abstract}
The report analysis the issues of the cadastre and the property (land) register, whose law regulation is Bulgarian Cadastre and Property Register Act. Restitution and privatization of immovable properties that took place some years ago were the main reason for performing a legal reform in this field. There is a long-term program of creation of cadastral maps and registers in Bulgarian. The priorities in this process are the regional and municipal centres and territories with active market like Black Sea coast or border zones.

Cadastre is a guarantee for: the right of ownership of immovable properties for territory of the whole country because it covers settlements, agricultural land, forests and other territories; secure transactions and mortgaging; limitation of court claims.
\end{abstract}

Key words: Cadastre; Property Register; Cadastre maps; Cadastre registers

\section{THE CADASTRE}

Cadastre has varied implementation. It serves for regional development - regulation of territories, land consolidation, forestry management, design of infrastructure, and statistical analyses. Cadastral information is used as a source for control of tax declarations, land management, regional development plans, thematic maps, efficient investments like infrastructure projects. Cadastre is basis for setting up of geographic information system.

The regional and municipality authorities use cadaster for developing strategies, environment protection, management of protected areas, territories of water sourses, protected coast lines, information for disaster recovery and repair works.

The cadastre is kept by the Agency of Geodesy, Cartography and Cadastre, that is an executive agency to the Minister of Regional Development and Urban Development. Cadastre Agency is the only one institution that serves the users with cadastral information.

The Agency is a legal entity, having its seat in Sofia and fulfiling its role through its 28 regional units- Geodesy, Cartography and Cadastre Offices, located in the administrative centres of all districts of the country. Its competency includes:

- creation and maintenance of cadastral maps and cadastral registers for the whole territory of the country 1 ;

- drafting acts and regulations in the field of cadastre and geodesy, as well as programmes and concepts on future development;

- administrative and technical servicing the public, state administration, municipalities and other users of cadastral information;

- maintenance of the state geodetic, cartographic and cadastral fund; 
- keeping the register of physical persons and legal entities, licensed to carry out activities in the filed of cadastre, geodesy and cartography;

- implementation of technical activities related to establishment of the geographic names, keeping the register of names;

- control for compliance with the legal framework [1].

The cadastre represents a set of basic data on the location, boundaries and dimensions of real estate in Republic of Bulgaria.

The basic cadastral object is a landed property that is any part of the earth's surface, including one under water, with boundaries in accordance with a title of ownership. Landed properties make up the entire territory of the country. Each landed property has the permanent use as of the land within the boundaries of which it is located. Objects of the cadastre are also buildings and self-contained objects in the buildings apartments, studious, shops, garages, recreation and health centres ect.

The cadastre provides information about the identifier that is a unigue number for each object. The first field of the identifier is up to five digits long and contains the identification code according to the Classification of administrative and territorial units. The second field is up to four digits long and contains the number of the cadastral area. The third field is up to four digits long and it contains the number of plot. In the fourth field, which has a length of up to three digits is the number of a building located in the plot. The fifth field is three digits long and contains the number of the facilities in the building.

Also for landed properties there is information on: border fixed by coordinates of the poins defining them, area, lasting purpose and use of the land and the address.

The data on the buildings include outline of the building, floor area, number of floors, destination, purpose and address.

Information about the facilities in the building includes the identifier, location, floor number and use.

The information about landed properties and buildings is provided by drawing sketches, and the information about self-contained objects - by drawing of charts.

In all cases there is information on the right of ownership and other property rights - data about acts, which are grounds for the ownership rights or other real rights.

The cadastral consists of cadastral maps and cadastral registers drawn up in graphic and written form as well as in digital form.

The cadastral maps and registers serve as basis for the creation of the land registry, the drafting of the development plans and investment projects.

The cadastral map is produced on the basis of cadastral plans, regulation plans, map of restored ownership, geodetic, photogrammetric and other surveys [2].

The cadastral maps mark the state boundaries, boundaries of administrative-territorial units, plot boundaries, boundaries of landed properties, buildings with their identifiers, names of places, streets, points of geodetic basis and schemes of the facilities in the building.

The cadastral registers are produced on the basis of information on registers to plans and maps or acts submitted by municipalities, regional authorities or individual citizens [3]. They contain basic information about the property - the owner and the act from which they draw their right. 


\section{THE PROPERTY REGISTER}

The property register is kept and stored by the Recordation Agency under the Minister of Justice, who supervises and controls the activity related to the property register.

The Property Register includes the acts which recognize or transfer ownership or establishing, transferring, changing [4] or terminating other property rights over real estate, as well as other actions, circumstances and legal facts to be entered as provided by law. Account is kept only for property that has an identifier. Each account consists of five parts.

Part "A" contains information about the main characteristics of the property such as identification number, type of property, boundaries, purpose [5], location, etc.

Part "B" contains information on the owner, their right to property, the act that gave rise to that right.

Part "C" of the consignment is intended to record the creation, transfer and termination of limited property rights [6].

Part "D" records data on the mortgages - their type, size and maturity of the claim to which they are established, the debtor, the cancellation of the mortgage [7].

Part "E", records data on the foreclosures on the property - the act which has been imposed, the amount of the claim which is awarded.

The entry in the Land Registry is carried out at the request of the person concerned, the notary or ex officio in the cases provided by law. The application needs to be submitted to the judge responsible for registration in accordance with the location of the property and it should contain the year, date, hour and minute of its receipt. Afterwards, a registration number is placed thereon.

\section{INTERCONNECTION BETWEEN CADASTRE AND PROPERTY REGISTER}

There is interconnection between cadastre and the property register through the identifier of immovable properties. Basic data about immovable properties in the property register are supplied from the cadastre and data regarding the right of ownership and other real rights over immovable properties in the cadastre are supplied from the property register. For the needs of the cadastre and the property register, a computerized information systems is established, which is mutually interlinked. The information systems also provides links with UCATTU (the Unified Classification of Administrative-Territorial and Territorial Units), BULSTAT (the Unified Classification of identification of legal entities), ESGRAON (the Unified System for identification of physical persons), Commercial Register (the Unified Classification of traders that may be physical persons or legal entities), registers of state and municipal properties;

The integral cadaster and property register information has three components:

- One set up for the Geodesy Cartography and Cadastre Agency needs, which supports the creating and maintenance of data;

- Another one set up for the Register Agency needs of property register data;

- The third one, called web portal, which provides users with access for search of data from both registers.

There is a variety in users of information. This can be:

- state, regional and municipal authorities, especially offices Agriculture and Forests [8]; 
- notaries;

- private geodetic companies;

- banks;

- real estate agents;

- investors;

- others.

The cadastre and the property register constitute public information, but access to data complies with the provisions under the Classified Information Act and Personal Data Protection

Act.

Fees are charged for the procedures in the cadastre and the property register. The amounts of the fees are determined by tariffs approved by the Council of Ministers.

\section{PERSONS AND ENTITIES COMPETENT TO PERFORM FUNCTIONS IN THE FIELD OF GEODESY, CARTOGRAPHY AND CADASTRE}

Functions in the field of cadastre may be performed by persons or entities who have acquired proper professional competence in cadastre subject according to Bulgarian law or to the law of other member states. The Geodesy, Cartography, and Cadastre Agency shall assign to such professionally competent bodies the performance of functions pertinent to creating the cadastral map and cadastral registers.

A property owner or another interested party can assign to a professionally competent body to produce sketches, charts, plans, a cadastral map and cadastral register.

A professionally competent body in geodesy, cartography, or cadastre may be a natural person of Bulgarian citizenship, of another member state, of a country of the European Economic Area Agreement or of the Confederation of Switzerland. This person has to hold an academic degree of Master-Engineer in geodesy and at least two years length of service in the field of the cadastre, geodesy or cartography and has not been convicted. It can be a Bulgarian legal entity or a entity of another member state, or of a state of the European Economic Area Agreement or of the Confederation of Switzerland. Its subject of activity should be the production of cadastre, respectively, geodesic and cartography activities, with professionally competent to perform geodesy, cartography, and cadastre activities person or persons in its permanent specialized staff.

Any professionally competent natural person may be a member of the permanent specialized personnel of no more than one legal entity.

An applicant for a position has to submit an application for entry into a register of the Geodesy, Cartography, and Cadastre Agency.

A committee, appointed by the Executive Director of the Geodesy, Cartography, and Cadastre Agency check, within 30 days following receipt of the application, whether the statutory requirements for entering the applicant into the respective register are met. The applicant is allowed to enter in the register by an administrative order issued by the Executive Director.

When the said statutory requirements are not met, the registration is denied. The applicant is notified in writing of such denial, and within two weeks following receipt of such notification may appeal against it before the Minister of Regional Development and Public Works.

The denial can be subject to appeal before the administrative court. Professional competence to perform functions pertinent to the cadastre, geodesy or cartography shall be acquired from the moment of entry of the applicant into the register 
of the bodies professionally competent to perform functions pertinent to the cadastre, geodesy and cartography. The information of the register is public.

\section{CONCLUSION}

We can summarize that nowadays building construction, investments or transactions of immovable properties are impossible without Cadastre and Land Register. By drawing cadastral maps and maintaining data about ownership and other real rights over real estates the state controls transferring, changing or terminating property rights and other actions, circumstances and legal facts. However, there are registered some problems about the punctuation in maps and data basis that led up to the idea of improving the legal framework and passing of new law. The reform should be carefully considered because changes could have other negative consequences like these appeared when in 2001 Bulgarian Cadastre and Property Register Act was enforced.

\section{REFERENCES}

[1] Dashina, E., Practical Problems by Implementation of Cadastre and Property Register Act, Property and Law, 2005, S., Trud i Pravo, EPI,online;

[2] Tanev, D., Cadastre and Law Security. The Philosophy of Cadastre and Property Register Act, Property and Law, 2006, 3, S., Trud i Pravo, EPI, online;

[3] Belcheva, M., The New Framework for Creating of a Cadastral Map. - Property and Law, 2006, 3, S., Trud i Pravo, EPI, online;

[4] Bakalova, V., Keeping of Cadastral Maps and Cadastral Registers in Currentl Condition Without Issuing of Change Order, Property and Law, 2015, 7, S., Trud i Pravo, EPI,online

[5] Bakalova, V., Discussion about the Purpose of Landed Properties and How They Are Included in Cadastral Maps and Registers according to Cadastre and Property Register Act, Property and Law, 2016, 12, S., Trud i Pravo, EPI,online ;

[6] Stojanov, V., Land Register, S., 2006, BAN, c. 23;

[7] Ivanov, D., I. Vasilev, Does the Mortgage on Land Include the Buildings Which Have Been Built Subsequently?, S., Pravna missal, 2016, 3, p. 55;

[8] Stojanov, V., S. Kurteva, U. Stoykova, Agricultural and Forest Land Legal Regulation, S., Trud i Pravo, 2011, p. 20. 